\title{
Use of Wollastonite as a Flux for Bone China Bodies
}

\author{
Lauren Arrussul Carús, Fabiana de Souza, and Saulo Roca Bragança \\ Postgraduate Program, Materials Department, Federal University of Rio Grande do Sul, Avenida Osvaldo Aranha 99/705, \\ 90035-190 Porto Alegre, RS, Brazil
}

Correspondence should be addressed to Saulo Roca Bragança, saulorb@ufrgs.br

Received 13 August 2012; Accepted 6 September 2012

Academic Editors: W.-C. Oh and O. P. Thakur

Copyright () 2012 Lauren Arrussul Carús et al. This is an open access article distributed under the Creative Commons Attribution License, which permits unrestricted use, distribution, and reproduction in any medium, provided the original work is properly cited.

\begin{abstract}
The utilization of wollastonite as a flux in bone china was investigated in this work. Ceramic industry is always looking to optimize the use of fluxes as a way of reducing energy costs associated with firing. Wollastonite is added in ceramic formulations as an auxiliary flux and allows fast firing production. However, its use in bone china has not been tested before. In the present work, two formulations were prepared, comparing the traditional formulation to another in which the conventional flux (potash feldspar) was partially replaced by wollastonite. The firing behavior, technical properties, microstructure, and phase development were analyzed. A slip with wollastonite was also developed to analyze its rheology. Wollastonite body achieved a reduction of firing temperature, a large plateau for firing, and optimal slip stabilization for casting pieces.
\end{abstract}

\section{Introduction}

Wollastonite is a calcium silicate. Both natural and synthetic minerals are used in ceramic formulations. Commercial wollastonite starts to melt at about $1450^{\circ} \mathrm{C}$ and cannot be considered a "flux" as alkali feldspar. For this function, it depends on the reaction with other raw materials. Its use is desired for rapid heating and cooling without cracking or warping. Other sources of $\mathrm{CaO}$, such as limestone, enhance loss on ignition [1]. Besides, wollastonite is interesting to use in white porcelain due its very low level of colorants oxides, such as $\mathrm{Fe}_{2} \mathrm{O}_{3}, \mathrm{FeO}$, and $\mathrm{TiO}_{2}$. The use of wollastonite has not been tested in bone china formulations.

Bone china is known for its high technical and aesthetical quality. Bone china properties are superior to others porcelains in terms of whiteness, brightness, translucency, and high mechanical strength. As it is produced with $50 \%$ of a recycled material such as calcined cattle bones, its use must increase in near future, due to the recent awareness of environmental preservation.

Glassy phase determines the temperature and the firing range of ceramics formulated with silicate raw materials. Glassy phase control is a key factor to reduce firing temperature, which means a direct reduction in cost associated with the fuel. Realizing this aspect, whenever possible, industry chooses to use strong fluxes. However, in the case of bone china, strong fluxes are difficult to use because of the short firing range, limited by low thermal stability of parts [2].

The overall composition of bone china lies in the eutectic region of $11 \%$ tricalcium phosphate, $38 \%$ silica, and $51 \%$ anorthite, with a melting temperature of $1290 \pm 5^{\circ} \mathrm{C}$. If the firing proceeds slowly at temperatures just above $1250^{\circ} \mathrm{C}$, the deformation of parts may occur. Therefore, the firing should be conducted in nonequilibrium conditions, forming the final phases that are anorthite, $\beta$-tricalcium phosphate, and a siliceous glass [3].

In fast firing, the composition of the glass phase changes from point to point in the region under consideration, according to the works of Iqbal et al. $[3,4]$. In these studies, the analysis of the chemical composition of glass phase performed by SEM/EDS showed a significant variation in the contents of $\mathrm{Si}, \mathrm{Al}, \mathrm{Ca}$, and $\mathrm{Na}$, for different areas within the microstructure and to points within the same region. For example, in glass close to $\beta$-tricalcium phosphate crystals, the $\mathrm{CaO}$ content varied between 2 and $50 \%$.

The fact of not achieving an equilibrium composition of the glassy phase during firing makes more complex to predict the optimal experimental conditions of firing cycle. Hence it 
TABLE 1: Chemical composition and phase analysis of raw materials.

\begin{tabular}{|c|c|c|c|c|}
\hline wt \% & Kaolin & Calcined bone ash & Potassic feldspar & Wollastonite \\
\hline $\mathrm{SiO}_{2}$ & 46.96 & 0.65 & 66.2 & 47.61 \\
\hline $\mathrm{Al}_{2} \mathrm{O}_{3}$ & 38.05 & 0.8 & 16.54 & 0.11 \\
\hline $\mathrm{Fe}_{2} \mathrm{O}_{3}$ & 0.46 & 0.12 & 0.15 & 0.14 \\
\hline $\mathrm{MgO}$ & - & 1.1 & - & \\
\hline $\mathrm{CaO}$ & 0.02 & 52.2 & 0.36 & 48.66 \\
\hline $\mathrm{Na}_{2} \mathrm{O}$ & 0.03 & 2.1 & 0.89 & \\
\hline $\mathrm{K}_{2} \mathrm{O}$ & 1.14 & 0.07 & 14.66 & 0.03 \\
\hline $\mathrm{TiO}_{2}$ & 0.03 & - & 0.03 & - \\
\hline $\mathrm{P}_{2} \mathrm{O}_{5}$ & 0.11 & 40.5 & 0.15 & - \\
\hline Others & 0.03 & 0.2 & 0.64 & 0.35 \\
\hline LOI & 13.2 & 2.3 & 0.38 & 3.1 \\
\hline \multirow{3}{*}{ Major phases } & Kaolinite & \multirow{3}{*}{ Hydroxyapatite } & Quartz & \multirow{3}{*}{ Wollastonite } \\
\hline & Quartz & & Microcline & \\
\hline & Muscovite & & Albite & \\
\hline
\end{tabular}

is very difficult to obtain a wide range for firing, and at the same time, to reduce the initial temperature of vitrification. In fact, a bad choice of firing cycle and body composition can easily lead to distortion, warping, or blistering of fired parts.

In the present study, wollastonite was chosen to partial replacement of feldspar, due to its successful use for fast firing of ceramic products. A higher level of $\mathrm{CaO}$ and $\mathrm{SiO}_{2}$ in bone china body may be favorable for reducing firing temperature, according to $\mathrm{CaO}-\mathrm{SiO}_{2}-\mathrm{Al}_{2} \mathrm{O}_{3}$ ternary diagram, if it is properly designed. It was expected that $\mathrm{CaO}$ reacting with other oxides and silicates would form a liquid phase of higher viscosity, increasing the resistance to deformation on firing (pyroplastic deformation of parts).

\section{Materials and Methods}

Two bodies were formulated according to the following raw materials proportions (in weight percentage):

(i) traditional bone china: 50\% calcined bone, $25 \%$ kaolin, and 25\% feldspar;

(ii) new body: $50 \%$ calcined bone, $25 \%$ kaolin, $15 \%$ feldspar, and $10 \%$ wollastonite.

Wollastonite $\left(\mathrm{CaSiO}_{3}\right)$ was supplied by the NYCO Minerals. Table 1 shows the chemical composition of raw materials, carried out by X-ray fluorescence (XRF model Shimadzu1800 ), and crystalline phases determined by X-ray diffraction (Philips model X'Pert MPD). Table 2 shows particle size distribution by laser diffraction (Model Cilas 1180). This analysis was performed after grinding up the raw materials to sieve in 325 mesh (opening of $45 \mu \mathrm{m}$ ).

The bone powder used here is from a company that produces handmade items and is a waste from cutting and polishing of bovine bones, previously cleaned with caustic soda $(\mathrm{NaOH})$. In laboratory, the bone powder was calcined at $1000^{\circ} \mathrm{C}$ and milled until $90 \%$ of the particles were smaller than $14 \mu \mathrm{m}$, as recommended in the literature $[5,6]$.
Table 2: Raw material particle size distribution. After wet milling.

\begin{tabular}{lccc}
\hline \multicolumn{4}{c}{ Raw material particle size distribution $(\mu \mathrm{m})$} \\
Sample & $\begin{array}{c}10 \%< \\
(\mu \mathrm{m})\end{array}$ & $\begin{array}{c}90 \%< \\
(\mu \mathrm{m})\end{array}$ & $\begin{array}{c}\text { Mean particle size } \\
(\mu \mathrm{m})\end{array}$ \\
\hline Calcined bone & 0.52 & 11.21 & 4.16 \\
Kaolin & 2.35 & 14.26 & 7.89 \\
Feldspar & 2.03 & 41.49 & 22.5 \\
Wollastonite & 1.13 & 29.55 & 12.78 \\
\hline
\end{tabular}

The body formulations of the raw materials were mixed into wet mill, dispersed with sodium silicate (solution in water), and passed through sieve 325 mesh. Next, the body was dried $\left(110^{\circ} \mathrm{C}\right)$ in an oven, moistened with water $(8 \mathrm{wt} \%)$, and granulated by sieving mesh $20(0.84 \mathrm{~mm})$. As a result, the ceramic bodies were formed in hydraulic press, comminuted by a mortar, dried, mixed by hand and again moist ( $8 \mathrm{wt} \%)$, granulated (sieve $20 \mathrm{mesh}$ ), and pressed (at $\sim 30 \mathrm{MPa}$ ) to $8 \times 20 \times 60 \mathrm{~mm}^{3}$ dimensions. The pieces were naturally dried for 48 hours and in an oven at $110^{\circ} \mathrm{C}$ for at least 24 hours. The density (in kerosene) of the dry parts was $\sim 1.90 \mathrm{~g} / \mathrm{cm}^{3}$. Tests were performed at least with 8 specimens of each test body formulation. The firing temperatures investigated ranged from 1180 to $1280^{\circ} \mathrm{C}$, in an electric muffle furnace. The bodies of the four proposed formulations were fired simultaneously for each test temperature. The heating rate was $150^{\circ} \mathrm{C} / \mathrm{h}$, and the dwell was 30 minutes at the maximum temperature.

The bodies were characterized for water absorption, linear shrinkage (per caliper), geometrical density (in an analytical balance and caliper), and four-point flexural strength tests [7]. Deformation on firing test (also known as pyroplastic deformation or sag test) was performed with 1 piece for each test condition, as described in Segadães [8]. The microstructure was observed in a scanning electron microscope (SEM-Jeol JSM-5800) with microanalysis by energy dispersive spectrometer (EDX-Noran). Samples were 
TABLE 3: Technical characterization of fired bodies.

\begin{tabular}{|c|c|c|c|c|}
\hline $\begin{array}{l}\text { Body/temperature } \\
\left({ }^{\circ} \mathrm{C}\right)\end{array}$ & $\begin{array}{c}\text { Water absorption } \\
(\%)\end{array}$ & $\begin{array}{c}\text { Shrinkage } \\
(\%)\end{array}$ & $\begin{array}{c}\text { Apparent density } \\
\left(\mathrm{g} / \mathrm{cm}^{3}\right)\end{array}$ & $\begin{array}{c}\sigma_{f} \\
(\mathrm{MPa})\end{array}$ \\
\hline \multicolumn{5}{|c|}{ Wollastonite } \\
\hline 1180 & 2.33 & 11.62 & 2.29 & $53.3 \pm 9.3$ \\
\hline 1200 & 0.01 & 13.67 & 2.43 & $62.4 \pm 8.1$ \\
\hline 1220 & 0.04 & 13.23 & 2.46 & $73.9 \pm 4.1$ \\
\hline 1240 & 0.02 & 13.10 & 2.34 & $58.8 \pm 8.2$ \\
\hline 1260 & 0.03 & 12.66 & 2.28 & $53.0 \pm 9.1$ \\
\hline 1280 & 0.00 & 12.47 & 2.25 & $52.6 \pm 4.3$ \\
\hline \multicolumn{5}{|c|}{ Feldspar } \\
\hline 1240 & 1.22 & 8.80 & 2.17 & $41.1 \pm 4.3$ \\
\hline 1260 & 0.06 & 9.65 & 2.22 & $54.0 \pm 4.1$ \\
\hline 1280 & 0.05 & 9.59 & 2.16 & $48.1 \pm 4.7$ \\
\hline
\end{tabular}

prepared for SEM by polishing (with sandpaper in decreasing particle size, ending with a suspension of alumina in wool), sometimes followed by acid etching (HF 20\%, at different times) to remove glass phase.

A slip casting was formulated with wollastonite, and then the density was adjusted to the proper value with addition of water, to make it comparable to the traditional formulation. The slip was prepared with $70 \%$ of solid and $30 \%$ of deionized water with addition of $0.15 \%$ deflocculant agent (ammonium polyacrylate). $1 \%$ of ball clay was added to the batch.

The characterization of the slip viscosity was made in a digital viscometer (model LVDV-II with small volume device, spindle SC4-18, Brookfield, Stoughton, MA). The deflocculant agent was added until the minimum viscosity was reached.

\section{Results and Discussion}

Firstly, it the firing curve, deformation on firing, mechanical strength, and microstructure were analyzed. Then, the rheology study was shown. The tests were performed for both bodies described previously.

3.1. Evaluation of Firing Behavior, Mechanical Strength, Deformation on Firing, and Microstructure. Table 3 shows the results of technological characterization. They are also discussed by means of Figures 1 to 6 .

Ceramic pieces must have water absorption lower than $0.5 \%$ to be classified as porcelains. Thus the firing curve shows the firing ranges for each body, which are formed by values of water absorption below $0.5 \%$. This curve also correlates water absorption to shrinkage, which may be around $12 \%$.

Feldspar body reached the desired vitrification only at $1260^{\circ} \mathrm{C}$ (Figure 1). It can be observed that feldspar showed lower fluxing strength compared to the body of feldspar and wollastonite. This behavior can be explained by the fact that a potassium feldspar was used, which consists mainly of microcline $\left(\mathrm{KAlSi}_{3} \mathrm{O}_{8}\right)$. Alkali feldspar that has higher levels of albite $\left(\mathrm{NaAlSi}_{3} \mathrm{O}_{8}\right)$ showed vitrification between $1220^{\circ} \mathrm{C}$

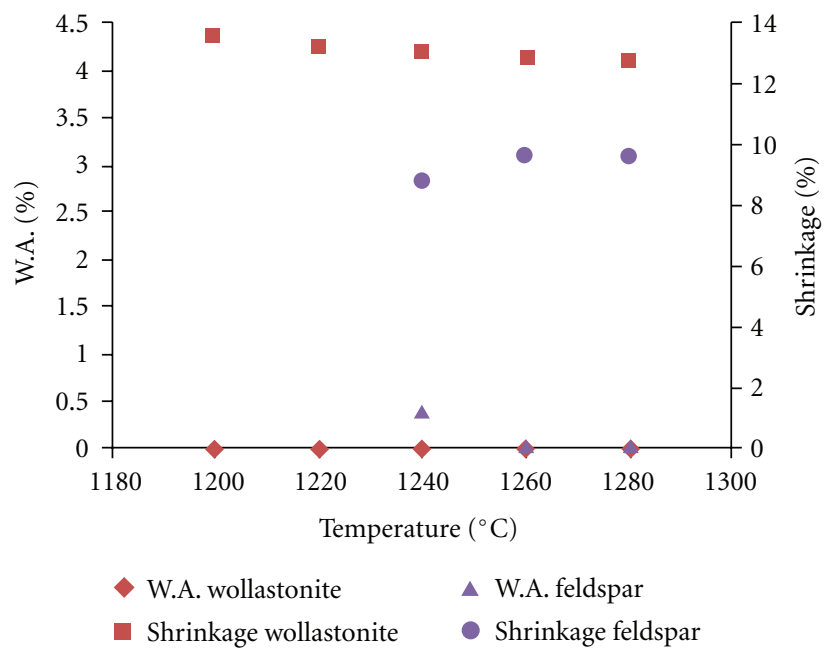

FIGURE 1: Linear shrinkage and water absorption (W.A.) as a function of firing temperature. Feldspar and wollastonite bodies.

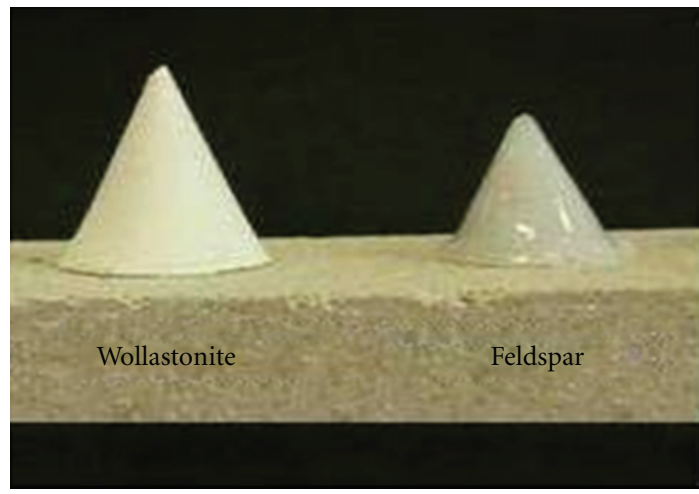

Figure 2: Fusion cone test for compositions of $100 \%$ flux. Temperature ramp of $150^{\circ} \mathrm{C} / \mathrm{h}$; fired at $1240^{\circ} \mathrm{C}$ for 30 minutes.

and $1240^{\circ} \mathrm{C}[2,9]$. Other studies, using conventional flux as alkali feldspar (richer in sodium than the feldspar used in this work) and/or nepheline syenite, showed similar firing ranges and, in some cases, lower ones $[2,9,10]$. It is noted that these are short intervals for firing, compared with other porcelains, 


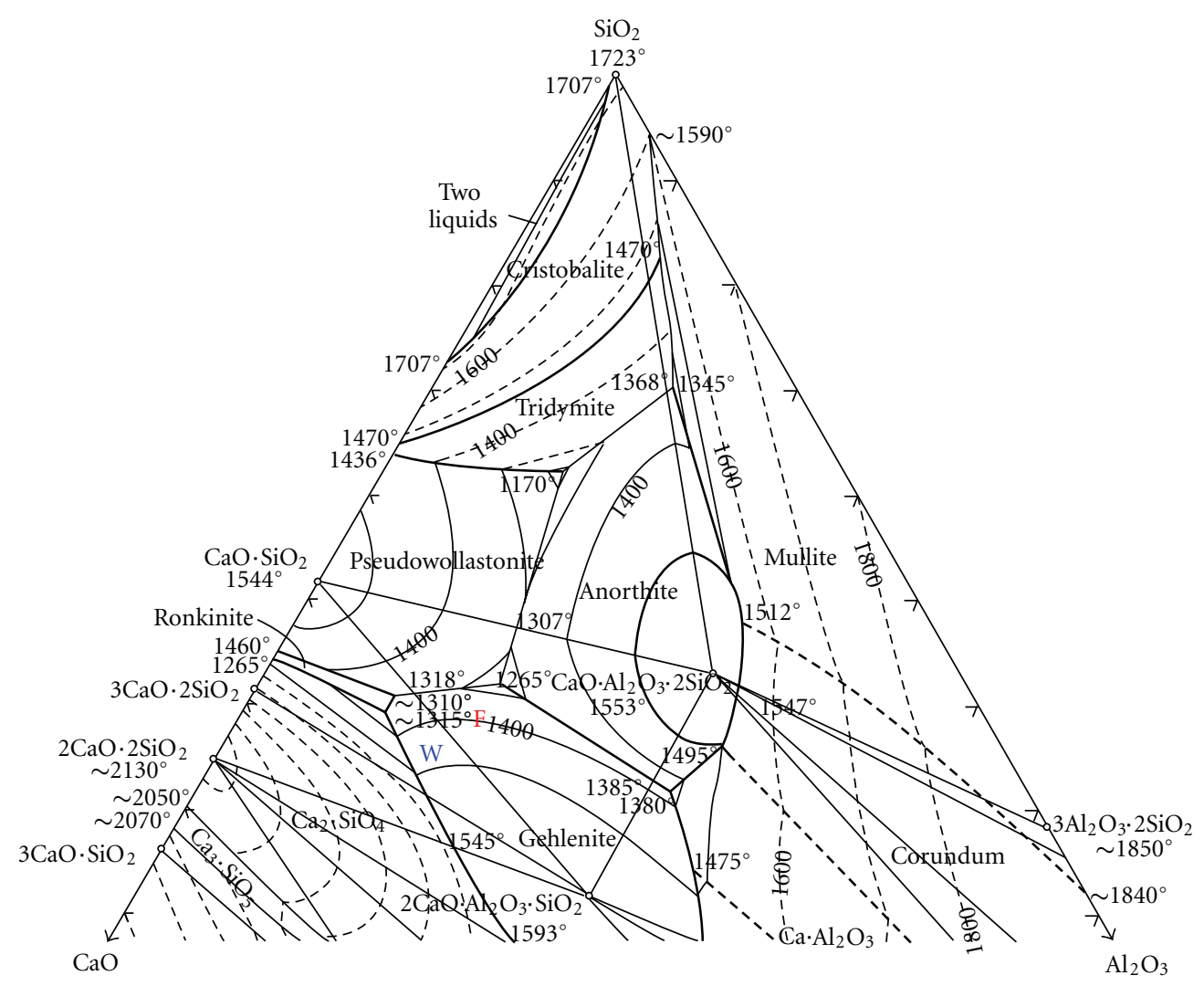

Figure 3: Feldspar (F) and wollastonite (W) bodies in $\mathrm{CaO}-\mathrm{Al}_{2} \mathrm{O}_{3}-\mathrm{SiO}_{2}$ diagram.

such as hard porcelain $[9,11]$. The difficulty to obtain higher firing ranges for bone china can be explained by the low amount of quartz. This phase undergoes gradual dissolution during firing, increasing the amount of silica in the glass phase, which ensures higher viscosity and, consequently, higher dimensional stability of the pieces at elevated firing temperatures [11, 12].

Figure 1 also shows the firing range for the body with wollastonite. The result is quite interesting, since the use of wollastonite reached a significant reduction of firing temperature, about $60^{\circ} \mathrm{C}$ compared to feldspar body, and at same time a wide range of firing was obtained.

Usually, commercial wollastonite melts at $\sim 1450^{\circ} \mathrm{C}$ and cannot be regarded as a flux in pure form. Figure 2 shows the cone fusion test. It is clear that wollastonite depends on the reaction with other compounds to give vitrification.

Wollastonite body was designed according to $\mathrm{CaO}-$ $\mathrm{Al}_{2} \mathrm{O}_{3}-\mathrm{SiO}_{2}$ ternary diagram [13]. Feldspar and wollastonite bodies' global composition is plotted in Figure 3. The wollastonite formulation falls within the triangle compatibility of $\mathrm{CaO} \cdot \mathrm{SiO}_{2}-3 \mathrm{CaO} \cdot 2 \mathrm{SiO}_{2}-2 \mathrm{CaO} \cdot \mathrm{Al}_{2} \mathrm{O}_{3} \cdot \mathrm{SiO}_{2}$, with an eutectic at $\sim 1310^{\circ} \mathrm{C}$, while feldspar formulation lies in neighboring triangle $\mathrm{CaO} \cdot \mathrm{SiO}_{2}-2 \mathrm{CaO} \cdot \mathrm{Al}_{2} \mathrm{O}_{3} \cdot \mathrm{SiO}_{2}$ $\mathrm{CaO} \cdot \mathrm{Al}_{2} \mathrm{O}_{3} \cdot 2 \mathrm{SiO}_{2}$, with an eutectic at $\sim 1265^{\circ} \mathrm{C}$. Based on Figure 3, the approximate initial liquid phase in the formulations would be $62 \%$ and $37 \%$ for the wollastonite and feldspar bodies, respectively. Wollastonite for developing a greater amount of liquid phase had a higher densification (and thus a reduction in the vitrification temperature).
The vitrification of wollastonite body could be explained by the presence of flux oxides even in low quantities (such as alkalis and FexOy). However, the amounts of these flux oxides are approximately the same as these of feldspar body.

According to literature, bone china firing behavior can also be explained by the presence of phosphorus oxide which forms metastable phases. In that case, the greater amount of calcium oxide and its presence in a more reactive form such as calcium silicate would contribute to reduce the firing temperature of wollastonite body. In this alternative way, $\mathrm{CaSiO}_{3}$ promotes the formation of bone china final phases, leaving a higher concentration of phosphorus oxide free. This oxide can lead to vitrification at lower temperatures, by means of phosphorus compounds with lower melting temperature, which do not appear in the final product, as proposed in Cooper [6] and Iqbal et al. [3, 4].

The deformation on firing test (sag test) showed that no deformation occurred in the parts for the temperature range studied. Therefore, the surface tension of glass phase was high enough to avoid distortion of the pieces, for both bodies tested.

To explain the lower firing temperatures and, at the same time, the wide range of firing obtained, it is proposed that wollastonite, providing higher amounts of $\mathrm{SiO}_{2}$ and $\mathrm{CaO}$ in glass phase, facilitates sintering by viscous flow, but without significantly changing the viscosity of the glass phase. In fact, a higher amount of calcium in glass phase increases the surface tension of glass phase [14]. Therefore, wollastonite can provide a lower temperature of vitrification, without 


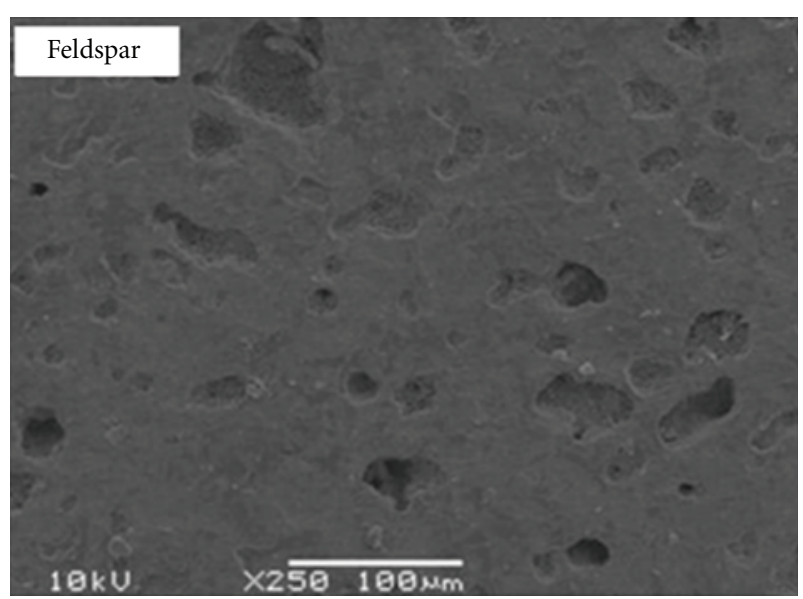

(a)

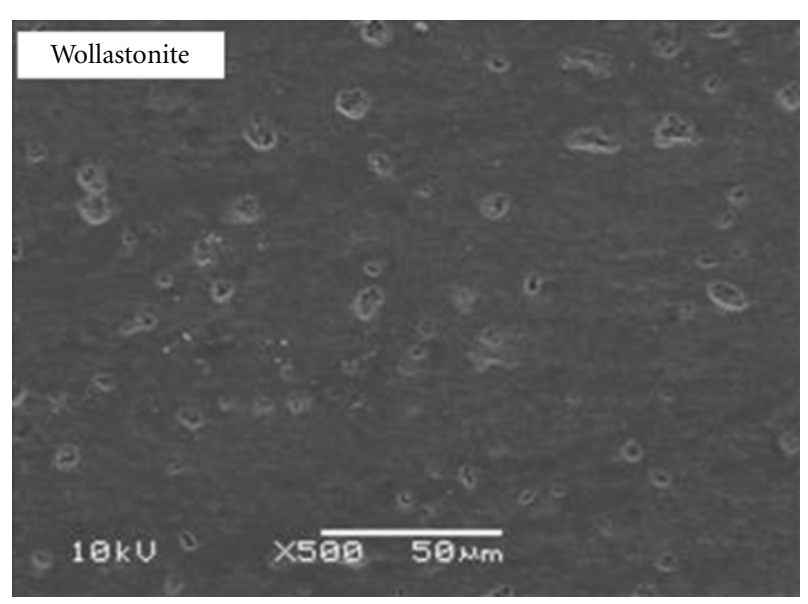

(b)

Figure 4: SEM micrographs. No chemical etching. Feldspar and wollastonite bodies fired at $1240^{\circ} \mathrm{C}$. Wollastonite shows small and closed pores.

compromising the resistance of pyroplastic deformation. Increasing the concentration of $\mathrm{Ca}^{2+}$ in the glass phase also improves the distribution of $\mathrm{Ca}^{2+}$ on the microstructure, because this does not depend only on diffusion from the hydroxyapatite particles. However, it is hard be demonstrated experimentally due to the heterogeneity of calcium in the glass phase composition within the microstructure. There was a wide variation in the levels of the main elements $(\mathrm{Ca}$, $\mathrm{Si}, \mathrm{Al}$ ) at different points in the glass phase, according to the analysis via EDS. The same was shown in the work of Iqbal et al. [3] .

Figure 4 shows microstructure of feldspar and wollastonite bodies. The difference of firing behavior is clear: feldspar body showed large pores and open porosity, while wollastonite had glassy phase covering the entire surface.

Table 3 shows the mechanical strength of the bodies. Both formulations achieved sufficiently high mechanical strength. The difference between the bodies can be explained by Figure 4: china mechanical strength is mainly a function of its phases and porosity. There is a direct relationship between pore size and the mechanical strength. That is, the larger

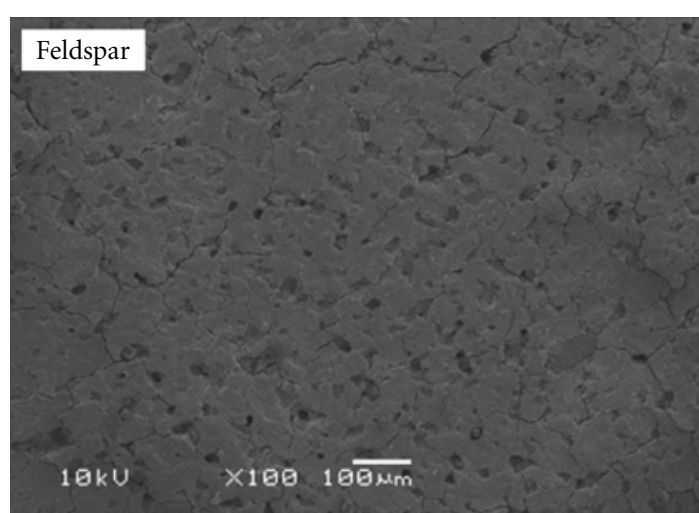

(a)

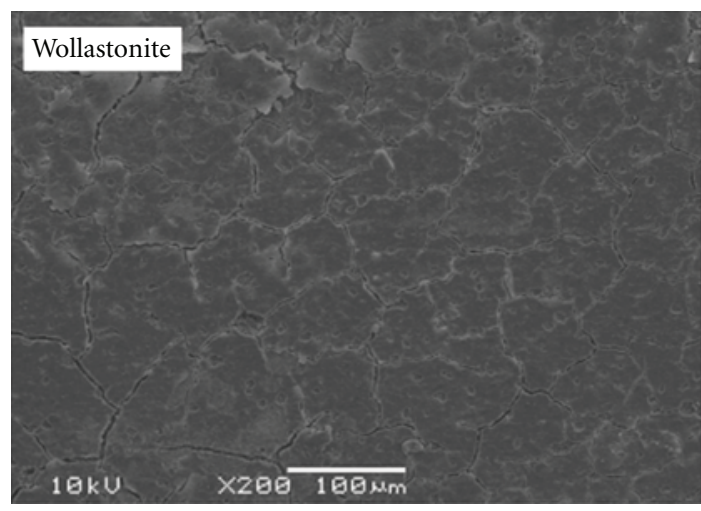

(b)

Figure 5: SEM micrographs. Chemical etching (HF 20\%, 20 s). Feldspar and wollastonite bodies fired at $1240^{\circ} \mathrm{C}$.

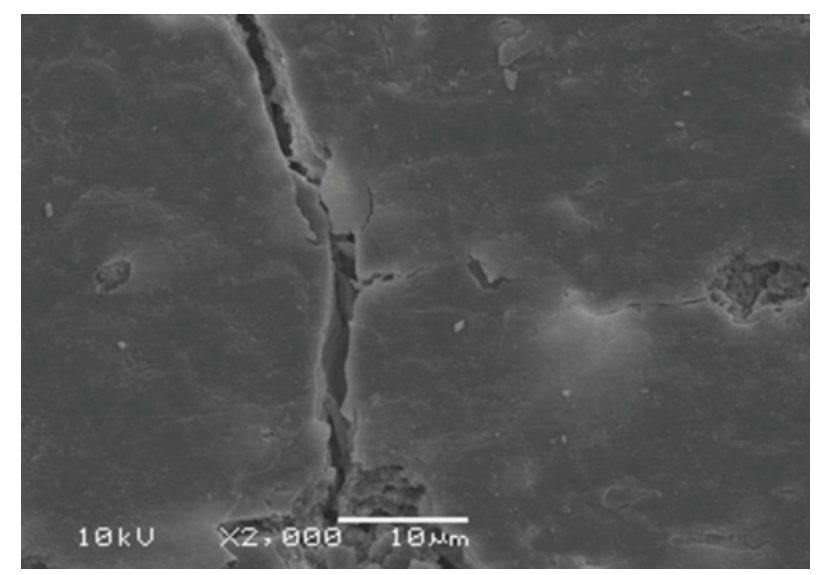

Figure 6: SEM micrographs. Chemical etching (HF 20\%, $20 \mathrm{~s}$ ). Wollastonite body fired at $1240^{\circ} \mathrm{C}$. Details of the fractured microstructure.

the pore size and the amount of porosity, the lower the mechanical strength $[15,16]$.

It can be emphasized that the most important factor is the size of pore/crack in the determination of so-called critical defect, according to the theory of linear elasticity fracture mechanics. Besides, the larger the amount of porosity, the greater the probability to have pores of larger sizes [15]. 


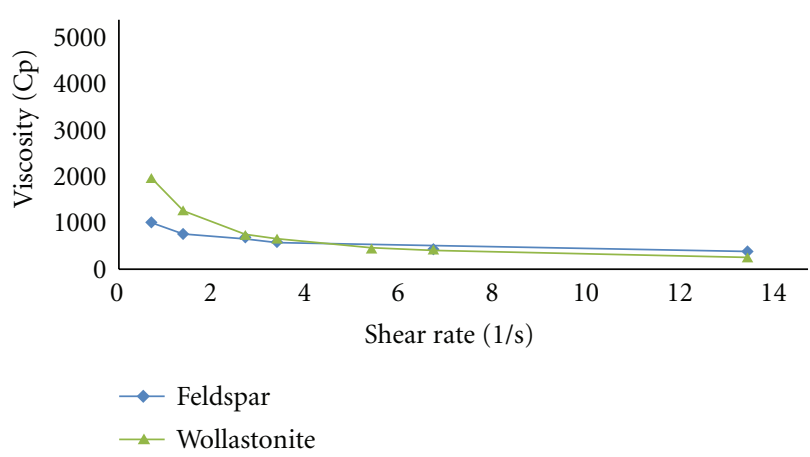

FIGURE 7: Shear stress in function of shear rate.

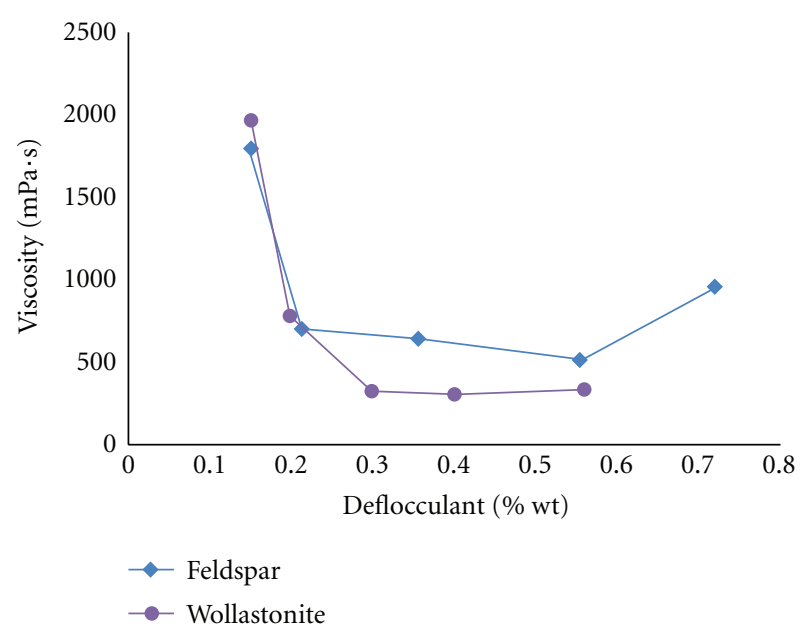

Figure 8: Viscosity in function of deflocculant amount. Wollastonite and feldspar slip bodies at $0.7^{s-1}$.

TABLE 4: Slip properties.

\begin{tabular}{lcc}
\hline Bodies & Feldspar & Wollastonite \\
\hline Slip density $\left(\mathrm{g} / \mathrm{cm}^{3}\right)$ & 1.796 & 1.817 \\
$\begin{array}{l}\text { Thickness wall-forming in } 1 \mathrm{~min}(\mathrm{~mm}) \\
\begin{array}{l}\text { Viscosity after deflocculation at } 0.2 \mathrm{wt} \% \text { of } \\
\text { dispersant }(\mathrm{mPa} \cdot \mathrm{s})\end{array}\end{array}$ & 3.58 & 3.58 \\
\hline
\end{tabular}

In Figures 5 and 6, using acid attack to remove glass phase, a fractured microstructure for both bodies can be seen. This occurs as a consequence of the stress generated due to the difference in thermal expansion between the matrix and the clusters of grains of $\beta$-tricalcium phosphate [4]. As cited before, the difference between bodies in pore size can be noted, notably higher for the feldspar body. These variations in porosity can be explained by the amount of glass phase, sintering temperature, and viscosity of the glass phase. Probably, there are also differences in grain size and amount of crystalline phase that can influence the properties of the bodies.

3.2. Slip Casting Characterization. Rheological curves of the both formulations are showed in Figure 7. It can be noted that the viscosity of the suspensions decreases as shear rate increases. This is a typical behavior of a Bingham curve, which is desired for porcelain slip $[17,18]$. It can be inferred from Figure 7 that the partial replacement of the feldspar flux did not change significantly the rheological behavior and the dispersant agent consumption (Figure 8). Thus, the leaching of ions from wollastonite raw material does not occur significantly. This could interfere with the stabilization of the slip. Thus, the control of viscosity and slip stabilization are practically the same as these of the feldspar slip.

Table 4 and Figure 8 exhibit the influence of deflocculant addition on the viscosity of the slips. For industrial practical purposes, both slips reached the same viscosity range for casting at $\sim 0.2 \mathrm{wt} \%$ of deflocculant (as the slips had already been prepared with $0.15 \%$, a total of $0.35 \mathrm{wt} \%$ dispersant was used). After this point, continuous additions of deflocculant cause an increase in viscosity by flocculating particles, as explained in literature $[17,19]$. Both slips showed similar casting properties (Table 4 ). The density and viscosity of both slips are good for porcelain production.

\section{Conclusions}

The use of wollastonite (partially replacing potash feldspar) in this work reached a lower firing temperature and an increased firing range, without occurring pyroplastic deformation of parts. Generally, bone china has short firing range. This adversity for bone china production was overcome with the utilization of wollastonite.

The reduction of the firing temperature obtained for wollastonite bodies is explained by a higher amount of glass phase according to $\mathrm{CaO}-\mathrm{Al}_{2} \mathrm{O}_{3}-\mathrm{SiO}_{2}$ diagram, compared to feldspar body. The wollastonite flux improved the viscosity of the glass phase by increasing the amount of calcium oxide in it, which allowed a larger firing range. This is a consequence of a higher level of $\mathrm{CaO}$ (and a higher distribution of $\mathrm{CaO}$ in the microstructure) which increases the surface tension of glass phase. A higher homogeneity of $\mathrm{CaO}$ level in microstructure is a result of two sources of $\mathrm{CaO}$ in raw material batch: bone ash and wollastonite.

Feldspar and wollastonite slip casting bodies showed similar rheological properties, with stabilized suspensions, and typical Bingham curves, for the range of shear stress, shear rate, and viscosity analyzed.

\section{Acknowledgments}

The authors acknowledge CNPq and CAPES for financial support.

\section{References}

[1] C. W. Sinton, Raw Materials for Glass and Ceramics, John Wiley \& Sons, New Jersey, NJ, USA, 2006.

[2] C. G. Portillo, "Influence of the type of melting on the properties of bone porcelain," Boletín de la Sociedad Española de Cerámica y Vidrio, vol. 38, no. 5, pp. 397-402, 1998.

[3] Y. Iqbal, P. F. Messer, and W. E. Lee, "Non-equilibrium microstructure of bone china," British Ceramic Transactions, vol. 99, no. 3, pp. 110-116, 2000. 
[4] Y. Iqbal, P. F. Messer, and W. E. Lee, "Microstructural evolution in bone China," British Ceramic Transactions, vol. 99, no. 5, pp. 193-199, 2000.

[5] D. Basnett and P. J. Cartwright, "Effect of bone properties on China casting," British Ceramic. Transactions and Journal, vol. 88 , no. 5, pp. 191-195, 1989.

[6] J. J. Cooper, "Bone for bone China," British Ceramic Transactions, vol. 94, no. 4, pp. 165-168, 1995.

[7] ASTM C-133/94, ASTM C-133/97. ASTM-American Standards for Testing Materials.

[8] A. M. Segadães, Refratários (Refractories), Universidade de Aveiro, Aveiro, Portugal, 1997.

[9] S. R. Bragança and C. P. Bergmann, "A comparative study between bone China and hard porcelain," Industrial Ceramics, vol. 28, no. 3, pp. 189-194, 2008.

[10] C. S. Prasad and K. N. Maiti, "Thermo-mechanical properties of bone China bodies," InterCeram, vol. 47, no. 4, pp. 221-228, 1998.

[11] K. H. Schüller, "Porcelain," in Ceramics Monographs-A Handbook of Ceramics, pp. 1-6, Verlag Schmidt $\mathrm{GmbH}$ Freiburg i. Brg, 1979.

[12] W. M. Carty, "Observations on the glass phase composition in porcelains," Ceramic Engineering and Science Proceedings, vol. 23, no. 2, pp. 79-94, 2002.

[13] J. F. Shairer, "Melting relations of the common rock-forming oxides," Journal of the American Ceramic Society, vol. 40, no. 7, pp. 215-235, 1957.

[14] J. M. F. Navarro and, El Vidrio (Glass), CSIC, Madrid, Spain, 1991.

[15] R. W. Davidge, Mechanical Behaviour of Ceramics, Cambridge University Press, Cambridge, UK, 1979.

[16] S. R. Bragança and C. P. Bergmann, "A view of whitewares mechanical strength and microstructure," Ceramics International, vol. 29, no. 7, pp. 801-806, 2003.

[17] J. S. Reed, Principles of Ceramic Processing, John Wiley \& Sons, Oxford, UK, 2nd edition, 1995.

[18] C. H. Schilling and I. A. Aksay, "Slip casting," in ASTM Engineered Materials Handbook, vol. 4 of Ceramics and Glasses. ASTM International, pp. 153-158, Cleveland, Ohio, USA, 1993.

[19] W. M. Carty and U. Senapati, "Porcelain—raw materials, processing, phase evolution, and mechanical behavior," Journal of the American Ceramic Society, vol. 81, no. 1, pp. 3-20, 1998. 

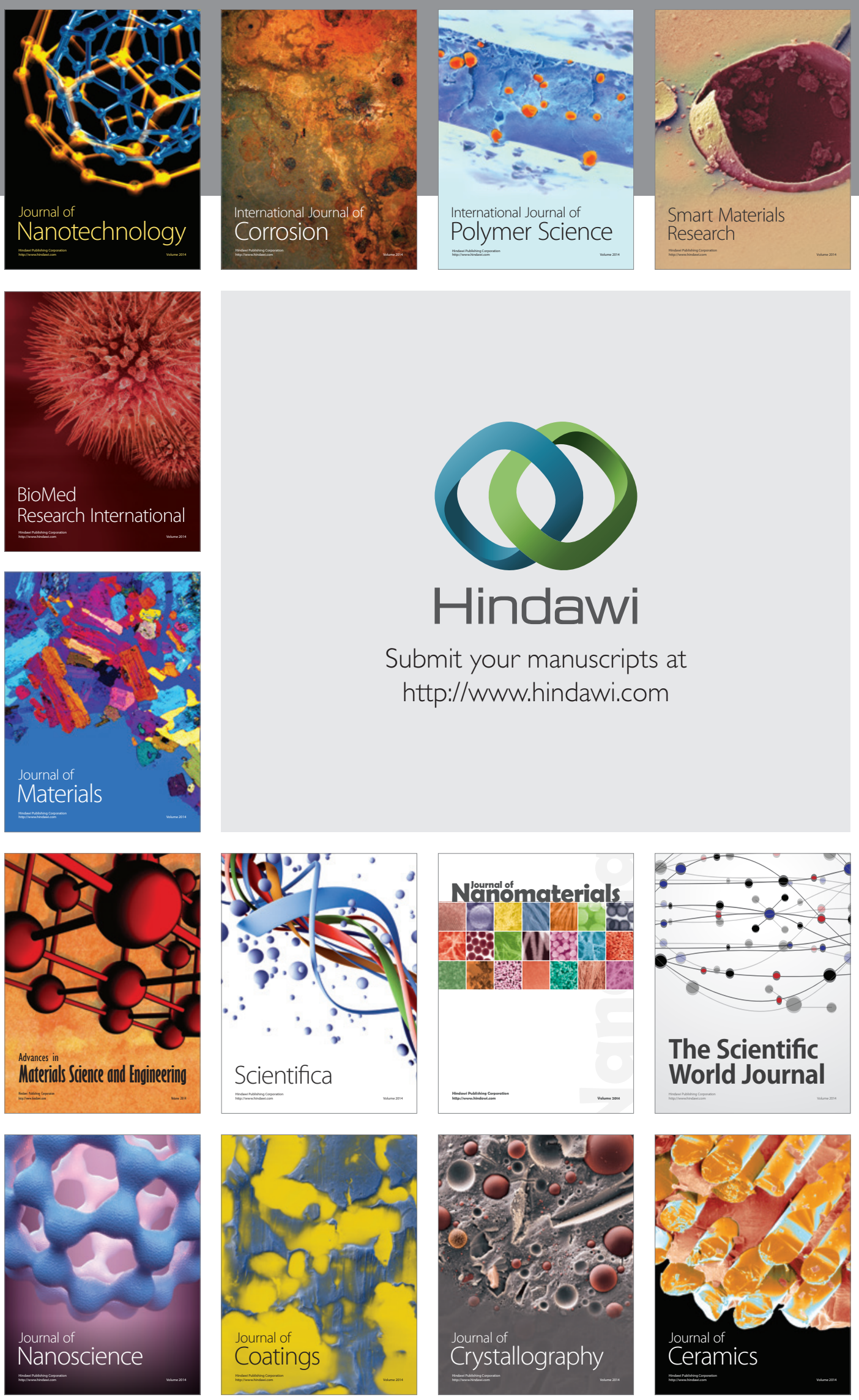

The Scientific World Journal

Submit your manuscripts at

http://www.hindawi.com

\section{World Journal}

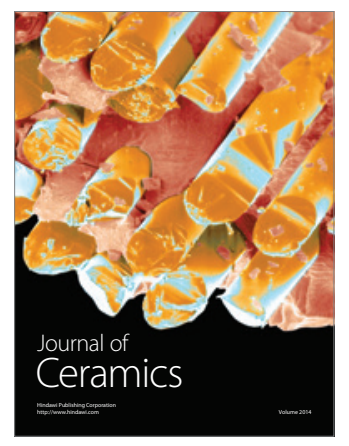

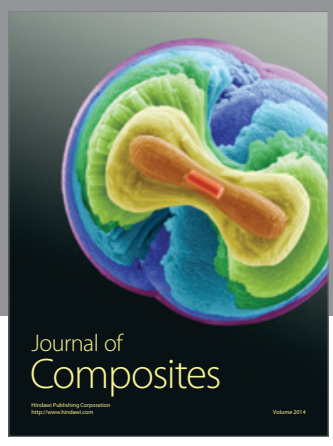
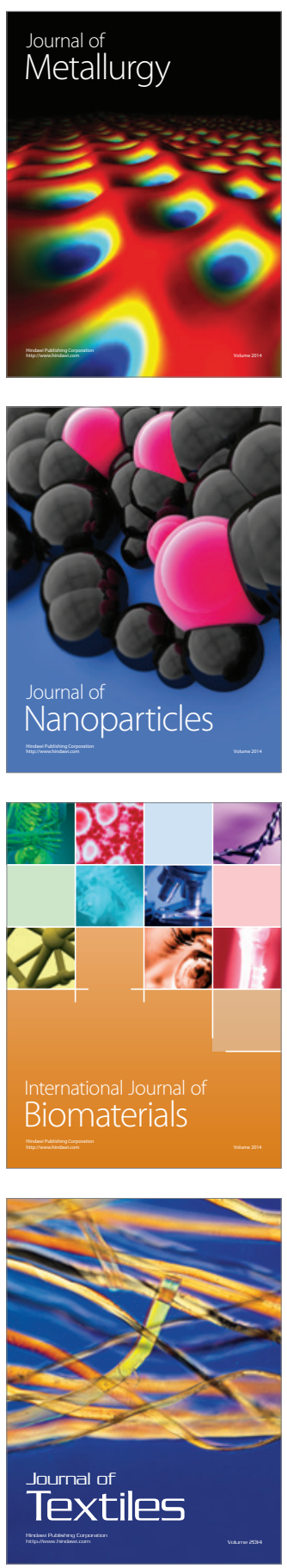